\title{
Influence of dibbling time and weather factors on seasonal dynamics of thrips (Thrips tabaci Lindeman) on garlic in Maharashtra
}

\author{
KARUPPAIAH, V., P. S. SOUMIA., S. J. GAWANDE., V. MAHAJAN and MAJOR SINGH \\ ICAR-Directorate of Onion and Garlic Research, Rajgurunagar, Pune, Maharashtra, India \\ *Email: karuppaiahv2008@gmail.com
}

\begin{abstract}
A study was conducted for three successive seasons (2014-17) to evaluate the effect of dibbling time on population dynamics of onion thrips (Thrips tabaci) on garlic dibbled on ten different dates starting from $1^{\text {st }}$ September to $15^{\text {th }}$ January at fortnight interval. The significant difference was observed in thrips population load among the dibbling dates. The garlic dibbled on early-December had maximum thrips load (41.8 thrips/plant) followed by both early and late-November sown crop (40 thrips/plant). The least mean of thrips population recorded with early-September planted garlic. Irrespective of sowing dates, highest thrips population peaks were recorded during $1^{\text {st }}$ to $6^{\text {th }}$ Standard Meteorological Week (SMW) of January and February. The maximum average of 59 thrips/plant were registered during early February $\left(5^{\text {th }} \mathrm{SMW}\right)$. The dry spell coupled with optimum temperature $\left(\operatorname{Tmax}=29\right.$ to $33^{\circ} \mathrm{C}$ and $\mathrm{Tmin}=9$ to $14{ }^{\circ} \mathrm{C}$ ) favoured thrips population build-up. The correlation analysis between thrips incidence and weather parameters showed significant negative correlation between thrips population and temperature as well as with precipitation.
\end{abstract}

Key Words: Thrips incidence, climatic variability, sown date, garlic, pest management

Garlic (Allium sativam L.) is one of the important bulb vegetables grown in India. The cloves are often used for seasoning and as condiment in number of forms for its flavour (Ferruci et al., 2010). The cloves containing properties are known for its medicinal value for various human health hazards like indigestion, anti-cancer, reducing blood pressure, heart diseases and arthrosclerosis (Bayan et $a l .$, 2014). In India, garlic is grown as a rabi vegetable and is planted mostly during October-November and harvested in March-April. Globally, India rank second position next to China in terms of garlic cultivation area (14\% of world area) and production (5\%) (Thangasamy and Chavan, 2017). The states including Madhya Pradesh, Gujarat, Rajasthan, Uttar Pradesh and Maharashtra are the major garlic growing states. However, the productivity is much lower than world average and is in static. Among the various constraints, insect pests are major constrains in garlic production.

Garlic hosts of many arthropod pests including mites (Karuppaiah et al., 2018). Among the different insect pest attacking garlic, onion thrips, Thrips tabaci Lindeman (Thysanoptera: Thripidae) is one of the key and destructive pest of garlic in India. The pest can cause yield losses either causing direct damage ( 15.35 to $46.82 \%$ ) or by transmitting viral disease (Gent and Schwartz, 2008); also aggravate fungal disease like purple blotch (Arantha, 1980). On garlic,
T. tabaci prefers to feed on young leaves confined to neck region of the plant. The pest sucks the plant sap, injured plants shows curling and blister white patches in the leaves that leads to reduction in photosynthesis ultimately resulted in formation of undersized bulbs (Hussein et al., 2015).

The attack of T. tabaci in garlic is prevailed in all the stages of crop growth. However, fluctuations in occurrence and population peaks are recurrent phenomenon that are predominantly regulated by various abiotic and biotic factors. Of these various abiotic factors, temperature and rainfall are the key factors that regulates the population fluctuations on garlic. Under changing climatic scenario, changes in agronomic practices for instance altering planting date, use of pest tolerant varieties, optimal use of water and nutrient would be some of mitigating strategies for sustainable crop protection (Mondal et al., 2013). In this context, the present study was undertaken to determine the effect of garlic dibbling date and weather factors on the occurrence of onion thrips on garlic under western Maharashtra, Pune.

\section{MATERIALS AND METHODS}

The present study was conducted during rabi seasons for three years (2014-15 to 2016-17) at ICAR-Directorate of Onion and Garlic Research, Pune $\left(18.32^{\circ} \mathrm{N} 73.51^{\circ} \mathrm{E}\right)$ under 
Table 1: Effect of dibbling date on thrips population (Pooled data for 3 years)

\begin{tabular}{llc}
\hline Dibbling time & \multicolumn{2}{l}{$\begin{array}{l}\text { Thrips population (Mean) } \\
\text { (Number of thrips/plant) }\end{array}$} \\
& $\begin{array}{l}\text { Actual value } \\
\sqrt{\mathrm{X}}+0.5\end{array}$ \\
\hline $\mathrm{D}_{1}-1^{\text {st }}$ September & 12.7 & $3.5^{\mathrm{d}}$ \\
$\mathrm{D}_{2}-15^{\text {th }}$ September & 30.6 & $5.4^{\mathrm{abc}}$ \\
$\mathrm{D}_{3}-1^{\text {st }}$ October & 30.0 & $5.5^{\mathrm{abc}}$ \\
$\mathrm{D}_{4}-15^{\text {th }}$ October & 35.2 & $5.9^{\mathrm{ab}}$ \\
$\mathrm{D}_{5}-1^{\text {st }}$ November & 40.0 & $6.3^{\mathrm{a}}$ \\
$\mathrm{D}_{6}-15^{\text {th }}$ November & 40.0 & $6.3^{\mathrm{a}}$ \\
$\mathrm{D}_{7}-1^{\text {st }}$ December & 41.8 & $6.3^{\mathrm{a}}$ \\
$\mathrm{D}_{8}-15^{\text {th }}$ December & 35.6 & $5.8^{\mathrm{ab}}$ \\
$\mathrm{D}_{9}-1^{\text {st }}$ January & 25.4 & $5.0^{\text {bc }}$ \\
$\mathrm{D}_{10}-15^{\text {th }}$ January & 20.5 & $4.5^{\text {cd }}$ \\
$\mathrm{CD}(0.05)$ & & 1.23 \\
\hline
\end{tabular}

*Values in the same column and different letters are significant at $5 \%$

All India Network Research Project on Onion and Garlic (AINRPOG). The garlic (variety: Bhima Omkar) was dibbled at ten different dates viz., $\mathrm{D}_{1^{-}} 1^{\text {st }}$ September, $\mathrm{D}_{2}-15^{\text {th }}$ September, $\mathrm{D}_{3}-1^{\text {st }}$ October (early dibbling); $\mathrm{D}_{4}-15^{\text {th }}$ October, $\mathrm{D}_{5}-1^{\text {st }}$ November, $\mathrm{D}_{6}-15^{\text {th }}$ November (normal dibbling); $\mathrm{D}_{7}-1^{\text {st }}$ December, $\mathrm{D}_{8}-15^{\text {th }}$ December, $\mathrm{D}_{9}-1^{\text {st }}$ January and $\mathrm{D}_{10}-15^{\text {th }}$ January (late dibbling). The experiments were laid out in randomized block design with three replications and bed size of $5 \mathrm{~m} \times 1.2 \mathrm{~m}$ in raised beds (broad bed furrow). The plant to plant and row to row spacing was followed as $10 \mathrm{~cm}$ and $15 \mathrm{~cm}$. The crop was irrigated at regular intervals with drip system. All the recommended agronomic practices were followed except insecticides application.

The visual counts were made to observe the thrips populations from $3^{\text {rd }}$ week of dibbling onwards and continued till maturity of the crop. The total number of thrips (nymphs \&adults) in top five leaves of each plant were counted. The count was made from five randomly selected garlic plants of each replication at weekly intervals. The weekly means of thrips population and date-wise means were also worked out. Before analysis, the data on thrips population were subjected to normalization using square root transformation. An analysis of variance was performed to determine the effect of dibbling date of garlic and location on thrips populations. The weather parameters including maximum temperature $\left(\mathrm{Tmax},{ }^{\circ} \mathrm{C}\right)$, minimum temperature $\left(\mathrm{Tmin},{ }^{\circ} \mathrm{C}\right)$;

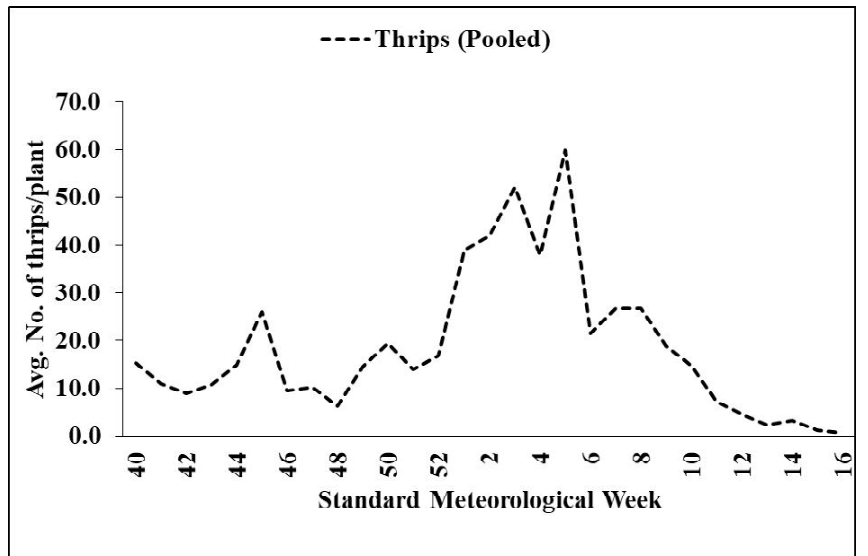

Fig 1 : Trend of T. tabaci on garlic during 2014-17 (Pooled data)

morning relative humidity at 7 am (RHI, \%), evening relative humidity at $2 \mathrm{pm}$ (RHII, \%) and weekly rainfall ( $\mathrm{mm}$ ) were also simultaneously obtained from institute observatory. Correlation analysis was performed between weather parameters and thrips population of pooled data of three years. All the test were performed at the 0.05 significance level.

\section{RESULTS AND DISCUSSION}

The pooled data (2014-17) on mean thrips populations among ten different garlic dibbling dates are presented in the Table 1. Among ten dibbling dates, the maximum thrips population (41.8 thrips/plant) were recorded in $1^{\text {st }}$ December planting date followed by $1^{\text {st }}$ November $(40$ thrips/plant) and $15^{\text {th }}$ November (40 thrips/plant) sown crop. However, population trend was statistically similar in all the three sown dates. On other hand, the garlic dibbled during $1^{\text {st }}$ September recorded least thrips load (12.7 thrips/ plant). Overall, date-wise mean showed significant $(p=0.05)$ difference in pest load among ten dibbling dates. The pooled data on weekly mean of thrips population revealed that, irrespective of dibbling dates population peaks mainly recorded during rabi months (January-February) i.e. $1^{\text {st }}$ to $6^{\text {th }}$ standard meteorological weeks (SMW). Besides, occurrence of one more peak during $45^{\text {th }}$ SMW was also recorded. The pooled data of three years weekly thrips population revealed the highest peak (59.8 thrips/plant) occurrence during $5^{\text {th }}$ SMW followed $3^{\text {rd }}$ SMW (52.2 thrips/ plant) and 26.7 thrips/plant during $7^{\text {th }} \& 8^{\text {th }}$ SMW and 26 thrips/plant during $45^{\text {th }} \mathrm{SMW}$. The lowest number of thrips $<3$ thrips/plant) was recorded in 12 to $16^{\text {th }} \mathrm{SMW}$. Overall seasonal trend revealed that $<30$ thrips/plant during $40^{\text {th }}$ to $52^{\text {nd }} \mathrm{SMW}$ (Fig 1). 

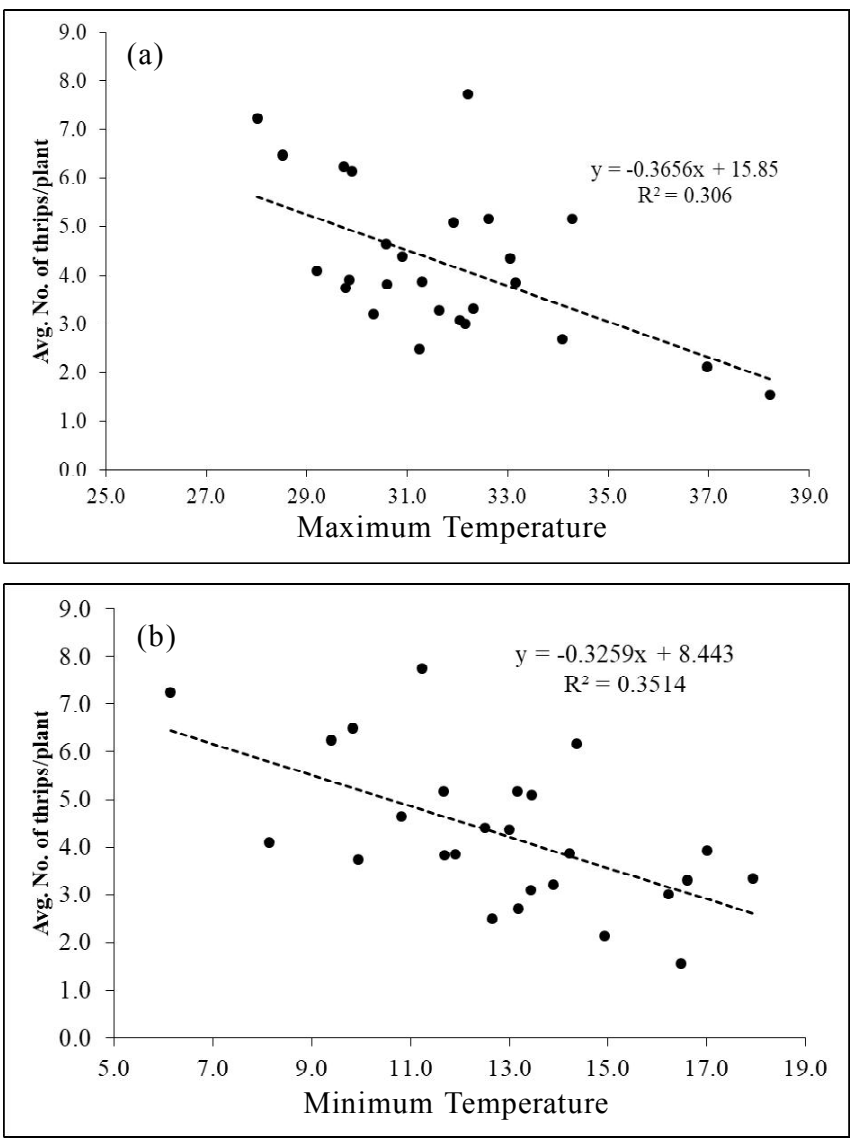

Fig 2 Relation between (a) Maximum temperature and

(b) Minimum temperature and thrips population

The garlic dibbled in early (September) and late seasons (January) had lower number of thrips load as compared to garlic planted in regular season (October to November) (Table 1). The similar trend of higher populations level was also registered in a month delayed dibbled garlic crop (December). The significant difference in seasonal mean populations shows that, the dibbling date can have an influence on garlic thrips dynamics. Dibbling of garlic by 15 days early ( $\left(1^{\text {st }}\right.$ October) exhibited significantly lower thrips load when compared to normal ( $15^{\text {th }}$ October $)$ dibbling date. The early season dibbling of garlic would help in avoiding the population peaks which are occurring regularly during January and February.

Correlation of weather parameters viz., maximum temperature, minimum temperature, morning relative humidity, evening relative humidity and total rainfall with thrips population showed variable relation. The highly significant negative correlation observed between thrips load and maximum $\left(r=-0.554^{*}\right)$ and minimum temperature $\left(r=-0.593^{*}\right)$. The morning relative humidity had non significant positive correlation $\left(\mathrm{r}=0.122^{\mathrm{ns}}\right)$ while evening relative humidity showed non significant negative correlation
Table 2: Correlation coefficients between thrips population and weather parameters (Pooled data)

\begin{tabular}{ll}
\hline Weather parameters & Thrips population \\
\hline Maximum temperature $\left(\mathrm{T}_{\max }\right)$ & $-0.554^{*}$ \\
Minimum temperature $\left(\mathrm{T}_{\min }\right)$ & $-0.593^{*}$ \\
Relative humidity at 7 am $(\mathrm{RH} \mathrm{I})$ & $0.122^{\mathrm{ns}}$ \\
Relative humidity at 2 pm (RH II) & $-0.169^{\mathrm{ns}}$ \\
Rainfall $(\mathrm{RF})$ & $-0.082^{\mathrm{ns}}$ \\
\hline
\end{tabular}

*Significant at 5\%. ns- Non-significant

$\left(r=-0.169^{\text {ns }}\right)$ and rainfall showed non significant negative correlation $\left(r=-0.082^{\text {ns }}\right)$ with thrips incidence (Table 2).

The seasonal dynamics of insect pests are mainly driven by abiotic factors (Prasad et al., 2008; Patel et al., 2009; Kataria et al., 2014; Maruthadurai, 2018). Likewise, the role of weather factors is indispensable while considering thrips population dynamics in garlic. In the current study, among the various weather parameters, temperatures found to be most influencing factors that had significantly negative relation with population build up. Most of the peaks were occurred within the temperature range of $29-33^{\circ} \mathrm{C}$ (Tmax) and $9-14^{\circ} \mathrm{C}$ (Tmin) (Fig 2a \& b). Total rainfall also had negative relation with thrips population. However, it did not show any significant correlation. This might be due to occasional or few rainy days experienced during entire seasons and crop gown in rabi months as may be the case. Furthermore, while population peaks $\left(1^{\text {st }}-6^{\text {th }}\right.$ SMW $)$ there was no rainfall recorded in corresponding weeks as well as preceding weeks. This shows that, dry spell coupled with prevalence ofoptimum temperature $\left(\operatorname{Tmax}=29-33^{\circ} \mathrm{C}\right.$; Tmin $=$ $9-14{ }^{\circ} \mathrm{C}$ ) could favours the thrips multiplication in garlic ecosystem. The present study was in accordance with the earlier findings by Janu et al. (2017) who reported significant negative relation between thrips population on cotton and maximum temperature. Similarly, negative correlation between thrips population and precipitation was reported by various workers (Shivanna et al., 2009; Sathyan et al., 2017).

\section{CONCLUSION}

The present study revealed that, dibbling date in garlic cultivation significantly influenced the thrips population dynamics. Early and late dibbled garlic crop harboured lower thrips population as compared to crop dibbled in normal season. Abiotic factors undoubtedly played major role in determining seasonal dynamics of thrips on garlic. Amongst the weather parameters, temperature play 
significant role in controlling thrips population dynamics on garlic. Thus, our study suggested that, early-October dibbling of garlic in around western Maharashtra region could avoid population peaks in the later bulb development and clove separation stage.

\section{REFERENCES}

Arantha, K.T.N. (1980). Thrips in vectors of plant pathogens. Academic press, New York. p. 149-64.

Bayan, L., Koulivand, P.S. and Gorji, A. (2014). Garlic: a review of potential therapeutic effects. AvicennaJ. Phytomed., 4: $1-14$.

Ferruci, L.M, Daniel, C.R, Kapu. K., Chadha, P., Shetty, H. and Graubard, B.I. (2010). Measurement of spices and seasonings in India: Opportunities for cancer epidemiology and prevention. Asia Pac. J. Cancer Prev., 11: 1621-1629.

Gent, D. H. and H. F. Schwartz. (2008). Iris yellow spot virus. In H. F. Schwartz and K. S. Mohan [eds.], Compendium of Onion and Garlic Diseases and Pests. 2nd edition. APS Press, Minneapolis, MN, pp. 80-83.

Hussein, S.H.A., Hanafy, A.R.I., Afsah, A.F.E., Maha, A. M. and Tantawy.(2015). Optimal time for insecticide applications to reduce the onion thrips, Thrips tabaci population on garlic crop and their effect on resultant yield. J. Plant Prot. Path. Mansoura Univ., 6 (2): 291-300.

Janu,A., Dahiya, K.K. and Jakhar, P.(2017). Population Dynamics of Thrips, Thrips tabaci Lindemann in American Cotton (Gossypium hirsutum).Int. J. Curr. Microbiol.App. Sci, 6(7): 203-209.

Karuppaiah, V., Soumia, P.S, Wagh, P.D. and Singh. M. (2018). Ephestia cautella(Lepidoptera: Pyralidae):An emerging pest on Garlic in storage. J. Entomol. Zool. Stud. 6(2): 2282-2285.
Kataria, S.K. and Pal. R.K. (2014). Infestation of Whitefly on different phenophases of cotton with respect to sowing dates and nitrogen levels. J. Agrometeorol., 16(1): $135-138$.

Maruthadurai, R. (2018). Effect of weather parameters on population dynamics of aphid, Aphis odinae (van der Goot) (Hemiptera: Aphididae) on cashew in Goa. $J$. Agrometeorol., 20 (1): 84-86.

Mondal, S., Singh, R.P., Crossa, J., Huerta-Espino, J., Sharma, I.,Chatrath, R., Singh, G.P., Sohu, V.S., Mavi, G.S., Sukaru, V.S.P., Kalappanavarg, I.K., Mishra, V.K., Hussain, M., Gautam, N.R., Uddin, J.,Barma, N.C.D., Hakim, A. and Joshi,A.K. (2013). Earliness in wheat: akey to adaptation under terminal and continual high temperature stress in South Asia. Field Crops Res., 151: 19-26.

Patel, P.V., Acharya, M.F. Gedia, M.V. and Vyas, H.J. (2009). Study on growing degree days and population dynamics of thrips, Scirtothrips dorsalis Hood (Thysanoptera: Thripidae) on castor. J. Agrometeorol., 11(1): 79-82.

Prasad, T.V., Nandagopal, V. and Gedia, M.V. (2008). Seasonal abundance of sesbania thrips, Caliothrips indicus Bagnall in groundnut. J. Agrometeorol., 10: 211-214.

Sathyan, T., Dhanya, M.K., Aswathy, T.S., Preethy, T.T., Manoj, V.S. and Murugan, M. (2017). Contribution of weather factors to the population fluctuation of major pests on small cardamom (Elettaria cardamomum) Maton. $J$. Entomol. Zool. Stud., 5(4): 1369-1374.

Shivanna, B.K., Nagaraja, D.N., Manjunath, M. and Naik, M.I. (2009). Seasonal incidence of sucking pests on transgenic $B t$ cotton and correlation with weather factors. Karnataka J. Agric. Sci., 22: 666-667.

Thangasamy, A. and Chavan, K. (2017). Assessment of dry matter accumulation and nutrient uptake pattern of garlic. Indian J. Hort., 74(1): 80-84. 